\title{
ENTREPRENEURSHIP IN EDUCATION
}

\author{
Maria Liana LĂCĂTUȘ, Camelia STĂICULESCU \\ University of Economic Studies, Bucharest, Romania \\ mlacatus2000@yahoo.com, camistaiculescu@yahoo.com
}

\begin{abstract}
This paper analyzes the importance of entrepreneurship in education. Originally, the entrepreneurship model is an economic model. But, nowadays, as educational domain became more attractive for entrepreneurs and technological changes created new opportunities for autonomy, decentralization, and customization in educational systems, entrepreneurship is a reality in education too. The new forms of education, such as virtual schools or online courses stimulated entrepreneurs to invest in education in the same mode as they would initiate businesses in domains more market oriented. They take risks to invest in education and are known as 'edupreneurs'. In the first part of the paper is discussing the role of entrepreneurship in education emphasizing the idea that education is a domain in that innovation is promoting and producing all the time and, due this, a domain of entrepreneurship. In the second part of the paper the new concepts of edupreneurship and edupreneur are used to express the essence of entrepreneurial initiative in education and to emphasize significant issues of educational entrepreneurship. In the last part various forms of edupreneurial initiative are presented. The conclusion of the paper is that edupreneurial initiatives may represent viable solutions for the problems that schools and school managers are facing nowadays.
\end{abstract}

\section{Keywords: entrepreneurship, educational entrepreneurship, edupreneurship, edupreneur}

\section{Introduction}

Entrepreneurship is a valid model in economy described in terms of changes, innovation, and initiatives and often associated with economic development Entrepreneurs are visionary people who dream to new technologies and products and act to make them real. They are risk takers searching for opportunities on the market that would allow them to make profit. This valuable economic model is now, more than ever, a reality in education too. The school became so much a domain of initiatives and innovations that many experts in education are speaking about our times as an 'educational entrepreneurship era' [1].

Schools are confronted with high expectations, but usually they ended to disappoint through their results and inability to correspond expectations. People will think that education is the solution to economic and social major problems, included productivity and competitiveness, or social equity, civic behaviour, technology, knowledge and efficiency of democratic mechanisms. This is why schools are constantly under pressure of change.

Schools have been criticized for deficiencies such as lack and inequality of results, inequitable practices, or quality of labour force. Traditional approach regarding improvement in education was administrative reforms in public schools. . Many national reforms were responses at 
some major events. In 1983, American education system was accused of undermining USA capacity to compete in world economy [2]. As a fact, authorities imposed reforms and asked school urgently to improve students' performances. Important changes affected curriculum, textbooks, teacher training system, educational technologies, and educational leadership.

Nowadays, schools need entrepreneurship [3]. They need to change and innovate themselves in order to meet requirements regarding education and employment. This is why entrepreneurship is much appreciated in education today. Managerial approach is considered not enough for schools to effectively face challenges existing in our times. School needs innovation, creativity, action.

\section{Innovation and change in education}

The entrepreneurship model comes from economy. Despite its ups and downs, economy has registered extraordinary performances and demonstrated amazing capacity to adapt to continually changing conditions due entrepreneurial activity as some experts would think.

Nowadays, educational domain became attractive for entrepreneurs. Due to changes in technology, education offers new opportunities related to autonomy, decentralisation and customisation. New forms of education such as virtual schools, online courses or distance learning encourage development of a new category of entrepreneurs interested to invest in educational domain in the same way as they would initiate businesses in other domains more market oriented. They are called sometimes 'education entrepreneurs' [4], other times 'educational entrepreneurs' [5] or simply 'edupreneurs' [6].

Edupreneurs are non-conventional educators who have created mainly new and most interesting models of instruction in our times despite the low percentage in educational system they represent. Their success is link to the risks they take when anticipate different needs and imagine probable solutions. Entrepreneurship involves imagination, creativity, talent and innovation. It is not an easy common way to act, but is a rewarded one. In bureaucratic structures such as public schools for example, decision makers normally do not choose risky alternatives or search for new ways to do things. On the contrary, they would avoid any risk and act according to validated procedures. This is the way public school administrators and educational authorities have to act. Usually, they are adepts of administrative reforms and believe that nowadays school can be improved through training and allocation of more resources. Many professional educators and would like to act in the same way too. They are hesitant when are confronted with risky alternatives and search for solutions that minimalize the risk: small classes, best practice solutions, more discipline and so on.

But, expertise, resources and research do not warrantee that problems in educational system will be solved. On the contrary, they can become enemies of excellence when they exist together with conventional wisdom and bureaucratic routine. New ideas and solutions appear when people are trying to do things differently and making errors than acting in established ways.

Entrepreneurship is a 'disruptive solution' [7], a non-linear progress. Functional solutions are changing in time. By definition, new ideas are unverified and new solutions appear in a process of trying and making errors. Entrepreneurship implies unpredictable things too. It is also linked with our limits in anticipating the future. Entrepreneurship means, together with taking risks, also the possibility to fail. But, when it comes about educational system, the promoters of entrepreneurship in education believe that the change in educational system is necessary and even there is always a possibility to fail, the 
dangers are higher if the school will remain as it is now.

Educational entrepreneurship is seen also as a consequence of market opportunities that appeared in educational sector. Entrepreneurs have identified such opportunities and are offering educational products or services being motivated by profit or not. Market opportunities are necessary conditions for entrepreneurship, but they are not sufficient alone. There are other conditions necessary too; entrepreneurs have to enter in the industry, get resources, recruit talents, compete fairly, and have benefits in the conditions of success.

Profit and success are not the only motivations an entrepreneur may have. Entrepreneurs are motivated by the desire to be independent, by dreams to do something, or joy to innovate. The key role of an entrepreneur is to innovate and to be permanently open to new [8]. In educational domain, are considered entrepreneurs those individuals who are bringing the new and the change. They are more educational leaders rather than managers or other kind of staff employed at different levels. Educational entrepreneurs are talented and highly motivated persons that initiate changes and react to changes and external opportunities.

\section{The edupreneurs}

Despite differences in different points of view regarding entrepreneurship, all exiting definitions emphasize that entrepreneurship means initiative, organizing and re-organizing economic and social mechanisms to transform resources and situations in practical outcomes, and taking risks.

Educational entrepreneurship is related to certain individual roles and behaviours. The educational entrepreneur or so called edupreneur is defined as 'a person who has served as an educator prior to organizing a business related to education and has invested time, energy, and capital to create, develop, and market a program, product, service, or technology to enhance learning.' [6]. They can be developers or editors of educational products and materials, providers of tutoring services, educational consultants, educational software providers, founders of independent schools, owners of shops specialized in educational products and so on. Some of them could be former employees in public educational system who decided to leave the system in order to make their dreams come true, others could be still in the system and act in entrepreneurial way.

No matter what position they have without or within educational system, edupreneurs are visionary thinkers that create new organizations in order to make things possible. They don't follow some established paths, but, if necessary, they innovate the ways in which things are doing too. Actually, the new organizations they create, for-profit or not for-profit, are alternatives at exiting public schools. As their builders, these new organizations can stimulate the change and development in a more rapid and dramatic way than other actors in educational domain. The most important resource they need and which is a real support for successful enterprise is the new vision on what educational system should in order to be better off. This is the extraordinary value all educational entrepreneurs have.

Educational entrepreneurs are defined as innovators that can produce changes in public system of education due to their characteristics and activities. The most important characteristic they have is the vision regarding the way in which things can be done better. They think beyond existing constrains and solutions. They have passions, act under the pressure of emergency to make real the visions they have, and are followed by others. Unless ordinary school administrators that usually are acting in the limits of available resources, edupreneurs are capable to identify new opportunities and resources 
and do more things than others think is possible. They do not ask if a think can be done, but ask how can be done. This gave them the power to make sense differently on what is possible or not.

Educational entrepreneurs can be: (i) businessmen who identify a market opportunity on public education system; (ii) educational leaders who want to change the system; (iii) leaders from non-profit sector with initiatives who are building organizations outside the system (alternatives to existing educational system). Some of them are known as 'school builders', other as 'talent builders' or 'tool builders and service providers' [8]. School builders are the best known educational entrepreneurs. They would like to have new schools with at least a particular innovation, e.g efficient use of

space or technology, or efficient discipline system. Talent builders are focusing on quality of education. They provide leadership, recruit, develop and support teachers and school leaders. Tool builders and service providers may develop data systems, curricula, and instructional devices or provide distance learning or new educational programs.

Four categories of entrepreneurial actions in education are common: (I) innovations inside public schools; (II) building private schools, which are part of formal educational system; (III) building private organizations part of non-formal educational system; (IV) public-private partnerships in education. Some examples of what they are doing in educational domain are presented in Table 1.

Table 1 Edupreneurs actions

\begin{tabular}{|c|c|c|}
\hline Edupreneur & Category of action & Example of action \\
\hline $\begin{array}{l}\text { Businessmen (i) } \\
\text { Educational leaders inside } \\
\text { the system (ii) } \\
\text { Leaders from non-profit } \\
\text { sector (iii) }\end{array}$ & $\begin{array}{l}\text { Building private schools } \\
\text { part of formal system (II) } \\
\text { Building private } \\
\text { organizations part of non- } \\
\text { formal educational system } \\
\text { (III) }\end{array}$ & $\begin{array}{l}\text { Getting recognition for a } \\
\text { new type of organization } \\
\text { or a new form of } \\
\text { instruction }\end{array}$ \\
\hline $\begin{array}{l}\text { Educational leaders inside } \\
\text { the system (ii) } \\
\text { Leaders from non-profit } \\
\text { sector (iii) }\end{array}$ & $\begin{array}{l}\text { Innovations inside public } \\
\text { schools (I) }\end{array}$ & $\begin{array}{l}\text { Introducing a new } \\
\text { educational program in } \\
\text { school }\end{array}$ \\
\hline Businessmen (i) & $\begin{array}{l}\text { Innovations inside public } \\
\text { schools (I) }\end{array}$ & $\begin{array}{l}\text { Providing a new } \\
\text { educational product to a } \\
\text { school, even competing } \\
\text { with existing providers }\end{array}$ \\
\hline Businessmen (i) & $\begin{array}{l}\text { Building private schools } \\
\text { part of formal system (II) }\end{array}$ & Building a new school \\
\hline $\begin{array}{l}\text { Businessmen (i) } \\
\text { Educational leaders inside } \\
\text { the system (ii) } \\
\text { Leaders from non-profit } \\
\text { sector (iii) }\end{array}$ & $\begin{array}{l}\text { Innovations inside public } \\
\text { schools (I) } \\
\text { Public-private partnerships } \\
\text { in education (IV). }\end{array}$ & $\begin{array}{l}\text { Enhancing public school } \\
\text { capacity (alternative } \\
\text { support programs for } \\
\text { teachers and school } \\
\text { principals, new products } \\
\text { and services for teachers } \\
\text { and school managers) }\end{array}$ \\
\hline
\end{tabular}

Educational entrepreneurship may be alternative sources for developing teachers, leaders, schools and instruments. They are agests of change. Authentic entrepreneurs 
are in action. They have to act. They act motivated by a strong need to do things, to create something new that will transform their visions into reality.

They also believe that they can change and control things and will have success due to their efforts. They are focused on success and are not discouraged by failures, difficulties or obstacles.

\section{Challenges and limits}

There are limits of educational entrepreneurship as consequences of existing regulations. Edupreneurs can build schools and implement innovative programs for different groups of students or promote quality in education. They target an unsatisfied or inadequate satisfied demand in public system of education. They innovate in different ways. In many cases, edupreneurs serves a thin segment of population and come with an customised educational supply special designed and developed for the expectation of that group.

Parents have avalability to pay for education private institutions are offering, fact that suggested that oficial educational system does not include different groups or that private institutions provide better education than public schools - maybe with better teachers, more well-trained staff, better conditions, better economic incentives, more diverse activities such as sports, personalized instruction, advanced technology, modern languages, civic/ maners/behaviour/character education.

In non-formal sector, edupreneurs are more active, mainly because it is less regulated. It is easier to register an organization such as a club, a play ground or an association that provide education without formal certification, than to build a school or a university. Non-formal educational organization have learners because nowadays there is an increasing need for instruction and formal system can't satisfay it. „Customers" of non-formal system may be university graduates who need new information and competencies, but not credits/degrees. This is a vaste space for innovation: professional training, modern languages courses, after school programs, summer schools/camps, moral education, leadership education, training for companies.

In non-formal education sector there are limits too, but others than in public education sector. There are regulations regarding certification and also barriers that make difficult entrance in educational domain. Private school has to have acreditations, aprovals to functioning, and obey management and financial regulations. This may lead to corruption too or may put limits to innovation. Teacher training programs has to be acreditated by state educational authorities or most representative universities. And this can replicate traditional teacher training system.

All these regulations are important barriers that make difficult for an edupreneur to enter and act in education market. Regulations are, no doubt, necessary in order to protect children and thier rights to a good education. But, they also need to be up-dated as the school reality is changing. This is not so easy to do, mainly because of bureucratical procedures applying in school decision making mechanisms or because educational authorities need support of majority actors in order to enact their policies. In addition to formal barriers, there are informal barriers, such as attitudes and believes that are change averse, too. Informal barriers are mainly related with people's idea of a ,real school' is. For most of them this is a school like they attended years ago [8] was good because they learned in that schools.

Educational entrerpeneurs have to demonstrate that innovation is efficient, and less costly. They also have to demonstrate professionalism and become less and less external actors or outsiders in this domain. But also government has to demonstrate the will to support educational entrepreneurship not only though subsidies, even they are important, but removing regulatory barriers, 
and shaping moral legitimacy of private educational enterprises [8].

Real challenge nowadays is to establish innovative educational systems that fight lack of performances and ensure continually improvement. The need for innovation is a reality in many educational domains, starting with curriculum and instruction in fields such as communication, sciences, technology and engineering, entrepreneurship education, civic education, leadership, or global education. Innovative thinking is needed in teacher and school manager training domain too, or vocational training.

\section{Conclusions}

Entrepreneurship is not a characteristic only of private schools, but also of public schools. As a fact, is more important in public schools due to the fact that public school leaders have to manage educational reforms in addition to requests of different customers. They have to effectively face diverse challenges and conduct activities - new instructional technologies, building a new school culture and structure, fund raising, educational marketing, networking - in order to improve conditions in their schools and even to transform the school environment.

\section{References}

[1] Hess, Frederick M, Welcoming the Entrepreneurial Era?, in Education Week, Vol. 26, Issue 10, 2006, Pages 32-40, at http://www.edweek.org/ew/articles/2006/11/01/10hess.h26.html

[2] A Nation at Risk: The Imperative for Educational Reform, 1983, Report of National Commission on Excellence in Education, at http://www2.ed.gov/pubs/NatAtRisk/index.html

[3] Drucker, Peter. Inovaţia şi sistemul antreprenorial, Ed. Enciclopedică, Bucureşti, 1993

[4] Smith, Kim; Petersen. Julie Landry, 2006, What Is Educational Entrepreneurship?, Written for Educational Entrepreneurship: Realities, Challenges, Possibilities, edited by Frederick M. Hess, Harvard Education Press 2006, at http:/gseweb.harvard.edu/hepg/educationalentrepreneurship.html

[5] Frederick M. Hess, Educational Entrepreneurship: Realities, Challenges, Possibilities, Harvard Education Press, 2006

[6] Charles W. Lavaroni, M.S. and Donald E. Leisey, Ed.D., Bringing the Excitement of Entrepreneurism to the Public Schools, at http://www.edentrepreneurs.org/edupreneur.php

[7] Christensen Clayton M. at all, Disruptive Innovation for Social Change, in Harvard Business Review, December 2006 Issue, at https://hbr.org/2006/12/disruptive-innovationfor-social-change

[8] McShane, Hess, Entrepreneurship and Innovation, in Handbook of Education Politics and Policy, second edition edited by Bruce S. Cooper, James G. Cibulka, and Lance D. Fusarelli, Rutledge, 2015, p. 304-320, [first edition published in 2008], at https://books.google.ro/books?id=qgkcBQAAQBAJ\&pg=PA320\&lpg=PA320\&dq=Hess, + Frederick + M.+(2006), + Educational+Entrepreneurship:+Realities, + Challenges,,+ Possibil ities, + Harvard + Education + Press\&source $=$ bl\&ots $=$ vQlGh000Gb\&sig $=$ gIbUunF_xHscJgH Mn2EK2gHw9rg\&hl=ro\&sa=X\&ved=0ahUKEwijkHjjO7LAhVnCpoKHYtiAOkQ6AEIQDAE\#v=oneage\&q=Hess\%2C\%20Frederick $\% 20 \mathrm{M}$ .\%20(2006)\%2C\%20Educational\%20Entrepreneurship\%3A\%20Realities\%2C\%20Challe nges $\% 2 \mathrm{C} \% 20$ Possibilities $\% 2 \mathrm{C} \% 20$ Harvard $\% 20$ Education $\% 20$ Press $\& \mathrm{f}=$ false 